\section{Footprints reveal reptiles showing their age}

A set of fossilized footprints found in the Grande Anse rock formation in New Brunswick, Canada, seems to nudge back the date of the earliest known reptiles. Previously, the oldest evidence of reptiles was fossil skeletons of Hylonomus lyelli found in Nova Scotia in 1859 and dated to about 315 million years ago. But a team led by Howard FalconLang of the University of Bristol, UK, has found reptile footprints a kilometre lower in the rock strata, indicating that they are between 1 million and 3 million years older than the previous find ( $\mathrm{H}$. J. Falcon-Lang et al. J. Geol. Soc. 164, 1113-1118; 2007).

of stem-cell lines derived before 15 June 2007. Harkin had attached the measure to the bill in June (see Nature 447, 1043; 2007).

\section{Demand made for UK marine-science agency}

A parliamentary committee has called for the establishment of a marine-science agency to oversee Britain's ocean research.

In a report released on 18 October, the House of Commons Select Committee on Science and Technology says that UK ocean research currently "lacks resources,

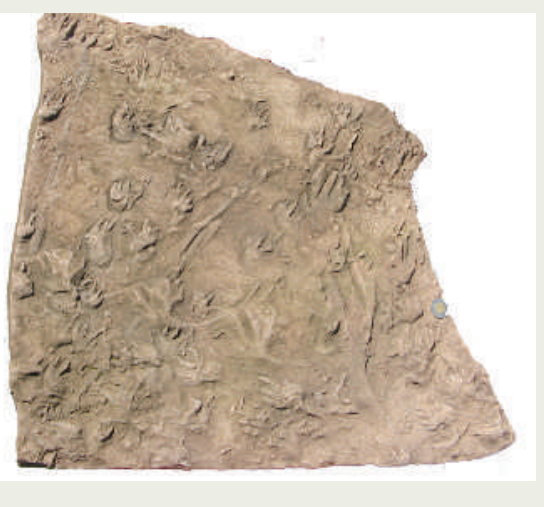

attention, coordination and an official champion". It suggests a new agency directly responsible for public outreach, education, working with industry and coordinating ocean observation.

The committee also calls for more marine-research funding, which it says has slipped by more than $10 \%$ since 2004 , to about $\mathfrak{E} 40$ million (US $\$ 82$ million) annually. Edward Hill, director of the National Oceanographic Centre in Southampton, UK, says that he agrees that the country's marine research has been fragmented and under-funded, and welcomes the report.

Jonathan Shaw, minister for marine and rural affairs, says that the government will introduce a marine bill early next year that may reflect the panel's recommendations.

\section{Only six EU nations meet research visa deadline}

The European Commission has told European Union (EU) nations to move faster to implement a directive that would make it easier for non-European scientists to work in their laboratories.

In a statement, commission vicepresident Franco Frattini urged member states to pass laws to implement the directive which, among other things, allows the visiting researchers to receive special visas with a fast-track procedure (see Nature $437,1215 ; 2005)$. He noted that the deadline for them to do so passed on 12 October, and warned that the commission would start infringement procedures if they failed to take prompt action.

So far only six member states - Austria, Belgium, Germany, Hungary, Portugal and Romania - have fully implemented the directive. Fifteen others are supposed to do so; the United Kingdom and Denmark, citing their special status under one of the EU treaties, have already said that they will not pass such laws. 